\title{
STRUČNÝ ETYMOLOGICKÝ SLOVNÍK SLOVENČINY A WINTEROVO PRAVIDLO
}

\author{
MARTIN PUKANEC \\ Filozofická fakulta Univerzity Konštantína Filozofa v Nitre
}

PUKANEC, Martin: Stručný etymologický slovník slovenčiny and Winter's Law. Journal of Linguistics, 2017, Vol. 68, No 1, pp. 89 - 96.

\begin{abstract}
This paper deals with several entries of the recent Slovak etymological dictionary Stručný etymologický slovnik slovenčiny (2015) from the point of view of Winter's Law. From this point of view, boh [God] (and, as the case may be, chod [motion, movement]) should have been originally borrowed from Iranian, koza [goat] should be regarded as a borrowing from Altaic languages, and sedlo ${ }^{1}$ [settlement] as well as sedlo ${ }^{2}$ [seat] as borrowings from Germanic. Moreover, from the point of view of Winter's Law, the etymological interpretation of modry [blue] and nevesta [bride] should be considered as too broad and the one of pôjd [loft] as inaccurate.
\end{abstract}

Keywords: etymology, Balto-Slavic accentology, Slavic accentology, Proto-Slavic, Slavic languages, Slovak language

V roku 2015 vyšiel Stručný etymologický slovník slovenčiny L'ubora Králika, ktorý je rozsiahlym, závažným a najmä nesmierne vítaným príspevkom do etymologickej diskusie na Slovensku, ked’že dovtedy sa v slovenskej jazykovednej obci pracovalo predovšetkým so slovníkmi Václava Machka (1957, 1968, 1971). Machkov Etymologický slovník jazyka českého vyšiel v niekol'kých reprintoch, a to aj celkom nedávno (2010), no tie nemohli poskytnút' aktuálne poznatky historickej lingvistiky a jej súčasti - etymológie. L'ubor Králik je mimoriadne kvalifikovaným etymológom (v slovenských podmienkach by sa žiadalo až zvolat' tanto nomini nullum par elogium) a vo svojom po všetkých stránkach výbornom slovníku ponúka najnovšie etymologické výklady, neuplatňuje v ňom však niektoré poznatky z oblasti balto-slovanskej a slovanskej akcentológie, kam patrí aj Winterovo pravidlo.

Winterovo pravidlo, ktoré bolo v pôvodnej formulácii Wernera Wintera (1978) definované ako predíženie samohlásky pred neaspirovanými znelými explozívami a v novšej interpretácii Frederika Kortlandta (1988) ide o glotalizáciu jadra slabiky pred glotálnymi konsonantmi, pričom sa tu generujú akútové vokály (no spoluhláska -s- či skupiny *-ngn- či *-ndn- pravidlo môžu blokovat'), musíme bez akýchkol'vek pochybností považovat' za vel'mi významné pravidlo, ked’že sa týka niekol'kých desiatok slov baltských a slovanských jazykov. Zdá sa byt' preto namieste otázka, či Winterovo pravidlo, a to bud' v Kortlandtovej interpretácii, ktorú v tomto príspevku budeme preferovat', alebo $\mathrm{v}$ tej tradičnejšej, ktorá napriek neutíchajúcej argumentácii F. Kortlandta (porov. aspoň 2011, s. 245) nie je ani zd’aleka prekonaná, významným spôsobom neovplyvní alebo nespresní aj výklady výrazov v etymologických slovníkoch. Toto sa teda na heslách Stručného etymologického slovníka slovenčiny pokúsime aspoň stručne a povrchne preskúmat'. 
Ak uvažujeme o etymológii ako o historickej jazykovednej disciplíne skúmajúcej pôvod, prvotný význam a príbuznost' slov (Slovník súčasného slovenského jazy$k a, 2006$, s. 913), nebude zrejme vel'mi prekvapujúce, že napriek rozšírenosti Winterovho pravidla môže ono podstatne zasiahnut' etymologický výklad len nepatrného množstva základných (neodvodených) výrazov. V etymologickom slovníku L. Králika sa dajú podl'a nás z perspektívy Winterovho pravidla na prvý pohl'ad zásadnejšie spochybňovat' závery iba v deviatich heslách: boh, sedlo (pod sedliak), sídlo, chodit', koza, voda, modrý, nevesta a pôjd. Tieto heslá postupne podrobíme krátkej analýze z daného uhla pohl'adu. Bokom tu nechávame prípady, kde sa dá rekonštruovat' indoeurópske východisko končiace sa na spoluhlásku s prídychom i bez neho (napr. stoh). V rámci etymologického kréda Jacoba Grimma, ktorého sa zjavne pridŕža aj Stručný etymologický slovník slovenčiny, podl'a ktorého chceme nielen stavat' domy, ale v nich aj žit', by beztak nemali vel'ký význam.

K heslu boh v danom slovníku L'. Králik uvádza, že pochádza z praslovanského *bogz ${ }^{l}$, ktoré súvisí so staroindickým bhájata ,rozdel'uje‘, bhágah ,kto pridel'uje, pán“ (čo je prívlastok bohov), tocharským A pāk, B pāke, diel, čast', gréckym fagein

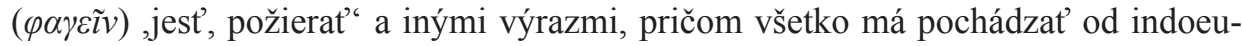
rópskeho *bhag- ,rozdel'ovat', určit' ako podiel'. K tomu dodáva, že pôvodným významom praslovanského ${ }^{*} \operatorname{bog}^{l}{ }^{l}$ bolo asi ,kto udel'uje, pridel'uje (materiálne statky ap.) ' a že význam ,boh' mohol vzniknút' i pod vplyvom iránskych jazykov, avestského baya či staroperzského baga- ,boh, pán“ (pozri Králik, 2015, s. 75). Podl’a Stručného etymologického slovnika slovenčiny teda praslovanský výraz *bogz pochádza z indoeurópčiny a len jeho význam mohol vzniknút' vplyvom iránskych jazykov.

Uvedený praslovanský výraz rekonštruujeme (pozri Derksen, 2008, s. 50; ESJS 2, 1990, s. 71) na základe staroslovienskeho bogz, srbského a chorvátskeho bôg, G sg. böga, slovinského bộg, G sg. bogâ, bulharského a macedónskeho bog, slovenského boh, českého bůh, G sg. boha, pol'ského bóg, G sg. boga, hornolužického bóh, G sg. boha, dolnolužického bog, ruského bog, G sg. bóga, ukrajinského boh, bih, G sg. bóha, a bieloruského boh, G sg. bóha, takže dôkladná praslovanská rekonštrukcia by bola *bôgz a slovo by patrilo do cirkumflexovej Stangovej paradigmy AP (c), nie do akútovej paradigmy AP (a), navyše indoeurópske *a ${ }^{*}$ *bhag- by v rámci Winterovho pravidla malo dat' praslovanské * $a$, nie * $o$, takže výraz *bôg $g$ je $\mathrm{z}$ akcentologického hl'adiska jednoznačným kandidátom na výpožičku.

Ked’že $\mathrm{v}$ tomto prípade nefunguje Winterovo pravidlo, musíme $\mathrm{z}$ akcentologickej perspektívy uvažovat' o možnosti, že ide o relatívne neskorú výpožičku z iránskych jazykov, najpravdepodobnejšie skýtskych, pretože Skýti dlho susedili so Slovanmi, a to najskôr až po období tzv. balto-slovanskej jednoty či akéhosi balto-slovanského paralelizmu - baltčina ostatne zodpovedajúci výraz ani nemá. Toto umocňuje ešte fakt, že vplyv iránskeho náboženstva na slovanské je celkovo vel'mi vel'ký (porov. Pukanec, 2013). S tým, že praslovanské *bôgъ je výpožičkou, treba podl’a 
nášho názoru súhlasit', lebo v prospech takejto etymologickej interpretácie významne svedčia - popri akcentológii - aj tieto argumenty.

Ďalšie dva prípady zo Stručného etymologického slovnika slovenčiny spomínané v našom výpočte nie sú ani zd'aleka také zrejmé. V prvom rade nie je vôbec isté, či sedlo a sídlo sú nepríbuzné heslá, čo ostatne, samozrejme, reflektuje aj rozoberaný slovník, a úvahy o týchto slovách navyše komplikuje skutočnost', že v slovenčine máme sedlo ${ }^{1}$ a sedlo i sídlo ${ }^{1}$ a sídlo ${ }^{2}$ (pozri Králik, 2015, s. 408, 523 a 529). V slovníku (heslo sedliak) sa teda uvádzajú dva praslovanské výrazy *sedlo. Prvé pomenovanie sedlo ${ }^{1}$, dnes už ako apelatívum zaniknuté, ktoré je vo význame ,osada, usadlost', dedina' zachované v miestnych názvoch typu Nová Sedlica, Sedlice, Sedliská ap. a z ktorého vzniklo aj slovo sedliak, má byt' z praslovanského *sedlo ,miesto na sedenie', z čoho potom vznikol význam ,miesto, kde sa možno usadit', osadit'; osa$\mathrm{da}^{6}$, a to má byt' z indoeurópskeho * sed-. Odkazuje sa tu následne na sídlo ${ }^{l}$. Pomenovanie $s^{2} d l^{2}$ - , sedacia čast' konského postroja' - ktoré nás bude teraz viac zaujímat', má byt' rovnako z indoeurópskeho *sed-, ale z praslovanského *sedblo, pôvodne asi ,čo slúži na sedenie‘, ako vidiet' i v staršom slovenskom sedlo vo význame „sedadlo“ (Králik, 2015, s. 523).

Praslovanský výraz pre druhé pomenovanie rekonštruujeme (pozri Derksen, 2008, s. 443 - 444; ESJS 10, 2000, s. 596) na základe cirkevnoslovanského sedblo, srbského a chorvátskeho sèdlo (čakavského sedlö), N pl. sëdla, slovinského sédlo, bulharského sedló, macedónskeho sedlo, slovenského a českého sedlo, pol'ského siodto, hornolužického sedło, dolnolužického sodło, staroruského sedblo, sedlo, ruského sedló, ukrajinského sidló a bieloruského sjadló. Dôkladnú praslovanskú rekonštrukciu uvádza slovník Ricka Derks ena ako *sed blò a výraz radí do novoakútovej Stangovej paradigmy AP (b), teda nie do očakávanej akútovej (staroakútovej), ako by sme podl'a Kortlandtovho výkladu Winterovho pravidla $\mathrm{z}$ indoeurópskeho *sed-predpokladali. Navyše $\mathrm{v}$ rámci Winterovho pravidla by indoeurópske * zo *sed-dalo praslovanské *ě.

Je praslovanské *sed blò kandidátom na výpožičku? Napríklad podl’a citovaného R. Derksena áno, má íst' o prevzatie z germánčiny, poukazuje na staroislandské soðull a starohornonemecké satul (pozri 2008, s. 444); - u- v prípone potvrdzuje rekonštruovaný jer (to ostatne aj to, že *-dl- bez jeru by sa zmenilo v daných praslovanských nárečiach na *-l-). Tu treba ešte poznamenat', že v starosaskom jazyku bolo sethal a stará horná nemčina mala aj sedal $<*$ sepla $<*$ sed-tlo (pozri heslo *sadula- ,sedacia čast' konského postroja ${ }^{*}$ - podl'a Kroonen, 2013, s. 419), čo ešte zvyšuje pravdepodobnost' výkladu, že v prípade $s e d l o^{2}<*_{\text {sed }}$ lò pôjde o prevzatie z germánčiny. Názor o opačnom smere vypožičiavania, o ktorom sa niekedy uvažuje ako o pravdepodobnejšom (pozri ESJS 10, 2000, s. 596), treba považovat' z hl'adiska Winterovho pravidla prinajmenšom za nepresvedčivý.

V Stručnom etymologickom slovníku slovenčiny sa d'alej uvádza, že slovenské sídlo ${ }^{l}$,priestor, v ktorom sa býva' vzniklo asi podl'a českého sídlo, ktorého východis- 
kom má byt' staročeské siedlo ako pravdepodobný variant pôvodného sedlo ,osada, usadlost'. Toto má byt' z praslovanského *sedlo, ktoré sme spomínali pri slovenskom výraze $s^{2} d l o^{l}$. L. Králik uvádza, že hláskový rozdiel elie môže súvisiet's potrebou odlíšit' tento výraz od českého sedlo ,čast' konského postroja ap.' (pozri 2015, s. 529). Okrem toho spomína výraz sídlo ${ }^{2}$,oko na povraze, slučka; pasca', ktoré môže pochádzat' z praslovanského *si-dlo, a to od indoeurópskeho koreňa *sēe(i)-, viazat" (pozri Králik, 2015, s. 529, 408). Ked’že tu by chýbal potenciálny glotálny konsonant (*-dlo < *-d lom, ale prípona je produktívna dodnes), toto $s^{\prime} d l l^{2}$ nás tu príliš zaujímat' nemusí.

Ak uznáme, že slovenské sídlo $o^{l}$ pochádza z češtiny a je variantom $\mathrm{k}$ sedlo ${ }^{I}$, čo je vel'mi pravdepodobné, otázkou ostáva len tento výraz. V Stručnom etymologickom slovníku slovenčiny sa, ako sme už uviedli, uvádzajú doklady miestnych názvov typu Nová Sedlica, Sedlice, Sedliská a podobne. Z diskusie o hranici medzi stredoslovenskými a nestredoslovenskými nárečiami sú v slovenskej jazykovede dobre známe doklady podobného typu názvov, $\mathrm{v}$ ktorých sa na mieste staršieho praslovanského *-dlnachádza *-l-. Z toho dôvodu je rekonštruovaný výraz bez jeru, čiže * sedlo, nesmierne zaujímavý, ked'že by tu mohlo dochádzat' k zmene *sedlò $>*$ selò.

Vel'mi t'ažko je však dokladat', či k zmene *sedlò > *selò v apelatívnej slovnej zásobe naozaj dochádzalo, lebo praslovanské *selò bude príbuzné s celým radom germánskych výrazov s -l- (pozri Kroonen, 2013, s. 424), ale predovšetkým aj s litovským salà a lotyšským sala (pozri Derksen, 2015, s. 387). Indoeurópske východisko musí mat' jednoznačne *-l- a v praslovanskom *sedlò treba potom zrejme na základe uvedeného vylúčit' mimoriadne produktívnu príponu *-dlo. Ak potom pri etymologickom výklade siahneme $\mathrm{k}$ indoeurópskemu koreňu *sed-, v jeho praslovanskom kontinuante bude podla Kortlandtovej interpretácie Winterovho pravidla znova absentovat' *ě i akút. $\mathrm{Z}$ toho dôvodu teda musíme $\mathrm{v}$ rámci tohto pravidla zrejme opät' uvažovat' o výpožičke z už spomínaného germánskeho * sepla (pozri tentoraz heslo *setla-; podl'a Kroonen, 2013, s. 434).

Nasledujúci slovenský výraz chodit’ je podl’a L. Králika (2015, s. 221) kontinuantom praslovanského slovesa *choditi, ktorý porovnáva so staroindickým $\bar{a}$-sad,íst' niekam, dosahovat', približovat' sa', avestským apa-had- ,odchádzat', gréckym hodos (ódós) ,cesta' a podobne. Toto všetko má byt’ od indoeurópskeho koreňa *sed,íst', ktorý môže byt' z hl'adiska pôvodu totožný s nám už známym indoeurópskym *sed-, pričom predpokladaný významový posun ,sediet" > ,íst" možno vysvetl'ovat' novým spôsobom dopravy (sediac na zvierati, resp. na voze), tak aj ruský vsádnik (всадник) je ,jazdec'.

Podl'a F. Kortlandta (1988, s. 394) a d’alších je chod jednoznačne deverbatívum od choditi, ale napríklad podla V. Machka (1971, s. 202) a iných je zas choditi od chod (porov. ESJS 4, 1994, s. 222). Pre toto chod sa v každom prípade uvádzajú ako doklady (pozri Derksen, 2008, s. 203; ESSJ 8, 1981, s. 51) staroslovienske chodb, srbské a chorvátske hôd, G sg. höda, slovinské hòd, G sg. hóda, a hộ, G sg. hodâ, 
bulharské chod, macedónske od, slovenské a české chod, pol'ské chód, G sg. chodu, hornolužické khód, dolnolužické chód, ruské chod, G sg. chóda, ukrajinské chid, G sg. chóda, a bieloruské chod; jeho praslovanská rekonštrukcia by bola *chôd a slovo by tak patrilo do cirkumflexovej Stangovej paradigmy AP (c), čiže by nemalo z indoeurópskeho koreňa *sod- na základe Kortlandtovej interpretácie Winterovho pravidla očakávaný praslovanský akút nad * $a$.

Môžeme tu počítat' s výpožičkou z iránčiny? Tak to uvádza napríklad Robert Beekes vo svojom slovníku pri hesle ódós (pozri 2010, s. 1047). Z hl'adiska hláskového vývoja je toto riešenie úplne bezproblémové, ba dokonca lepšie ako jemu konkurujúce vysvetlenie, lebo v ňom nevyhnutne nemusíme počítat's predponami, ktoré zmenia indoeurópske ${ }^{*} s$ na $* c h$ v rámci pravidla ruki. Rôzne (aspoň zdanlivé) ablautové stupne v koreni daných slovies však predpoklad výpožičky značne oslabujú. F. Kortlandt (1988, s. 394) prišiel s vysvetlením, že ,the only true counter-example to Winter's law“* *hod- je zo známeho zdvojeného koreňa *sizd- (k nášmu indoeu-

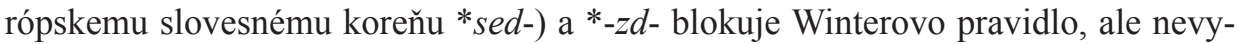
zerá to príliš presvedčivo; asi preto aj R. Beekes toto neprijíma. Ked’že o. i. tiež Этимологический словарь славянских языков (ESSJ 8, 1981, s. 49) počíta s prvotnost'ou *chods (nie *choditi), možno vari - s vel'kou mierou neistoty - pripustit', že môže íst' o prevzatie iránskeho had.

Ďalšou potenciálnou výpožičkou môže byt’ substantívum koza. Ako uvádza už L. Králik, tento výraz, ktorý pochádza z praslovanského *koza, môže byt’ na jednej strane bud' príbuzný so staroindickým ajáh ,cap', staroperzským azak,koza ‘ či litovským ožỹs ,cap“ a potom pochádzat’ z indoeurópskeho *aǵ- alebo dlhého *āǵ-, ktoré môže byt' vari zachované v odvodenom srbskom cirkevnoslovanskom azno ,stiahnutá koža', hoci vznik začiatočného * $k$ - by bol nejasný. Alebo, na strane druhej, môže íst' o prevzatie z altajských jazykov, lebo vo význame ,koza' poznáme turecké keçi, ujgurské käčki, čuvašské kačaka a i. (pozri Králik, 2015, s. 295).

Praslovanské pomenovanie rekonštruujeme (pozri Derksen, 2008, s. 242; ESJS 6, 1996, s. 350) na základe staroslovienskeho koza, srbského a chorvátskeho kòza (čakavského kozä), A sg. közu, slovinského kóza, bulharského kozá, macedónskeho koza, slovenského, českého, pol'ského a hornolužického koza, dolnolužického kóza, ruského kozá, A sg. kozú, ukrajinského kozá a bieloruského kazá ako *kozà a slovo by patrilo do novoakútovej Stangovej paradigmy AP (b), teda nemalo by akút nad * $a$ v prvej slabike, ktorý by sme predpokladali v rámci Winterovho pravidla, čo hovorí v prospech výpožičky. Ako navyše uvádza Jiří Rejzek, zemepisné rozšírenie uvedených indoeurópskych slov tejto domnienke vyhovuje (pozri Rejzek, 2001, s. 308), s čím môžeme, samozrejme, s ohl'adom na akcentológiu len súhlasit'.

Prípad pomenovania voda je úplne odlišný od predchádzajúcich výrazov. Ostatne už samotná reália, ktorú slovo pomenúva, nenabáda príliš k úvahám o výpožič- 
kách, hoci samotný W. Winter ich pripúšs’al (pozri 1978, s. 441). K heslu voda v danom slovníku L. Králik uvádza, že rovnaké praslovanské *voda súvisí s chetitským watar, staroindickým udán, tocharským A wär, B war, voda', arménskym get ,rieka', gréckym hydōr (v̋ $\omega \rho)$, albánskym ujë ,voda', latinským unda, vlna (vodná)', gótskym watō, nemeckým Wasser, anglickým water, litovským vanduõ, lotyšským ûdens ,voda ' atd'., pričom všetko to má byt' z indoeurópskych koreňov končiacich na pre nás závažné *-d (pozri Králik, 2015, s. 665).

Praslovanský výraz rekonštruujeme (pozri Derksen, 2008, s. 523; ESJS 18, 2016, s. 1074) na základe staroslovienskeho voda, srbského a chorvátskeho vòda (čakavského vodä), A sg. vödu, slovinského vóda, vôda, bulharského vodá, macedónskeho voda, slovenského a českého voda, pol'ského a lužickosrbského woda, ruského vodá, A sg. vódu, ukrajinského vodá a bieloruského vadá, takže znenie s prízvukom by bolo * vodà a pomenovanie by patrilo do cirkumflexovej Stangovej paradigmy AP (c). Chýbajúci akút však vysvetl'ovat' výpožičkou netreba, pretože na základe litovského vanduõ, G sg. vandeñs, či staropruského wundan a unds (pozri Rejzek, 2001, s. 718), teda s nosovým infixom zo sufixu, ako je to i v latinskom unda, môžeme rekonštruovat' balto-slovanské *wondōr, G sg. *(w)undnes, a hlásková skupina *-ndn- blokuje Winterovo pravidlo; takto to napokon vysvetl'uje sám F. Kortlandt (pozri 1988, s. 388). Sem inak patria aj v rámci Winterovho pravidla problematizované pomenovania zodpovedajúce slovenskému siahnut'. No ako uvádza aj L. Králik, siahat' bude pochádzat' z praslovanského *sęgati (*seng-) a to je najskôr od indoeurópskeho *seg-, *seng- (pozri 2015, s. 529); v slovese *sęgnoti (> siahnut') vidíme potom - na rozdiel od *sęgati - blokujúce *-ngn-.

Pomenovanie modrý pochádza podla Stručného etymologického slovníka slovenčiny z praslovanského *modrb, ktoré má azda súvisiet’ so staroindickým mádati „kypí, vyviera', gréckym madaō ( $\mu \alpha \delta \alpha \dot{\alpha} \omega)$,som vlhký premočený, nasiaknutý či latinským madēre ,byt' vlhký, mokrý', čo by potom bolo s možným významovým posunom ,mokrý, vlhký‘ > ,mútny, nejasný، > ,modrý ${ }^{6}$ od indoeurópskeho koreňa *mad- ,mokrý; stekat', kvapkat" (Králik, 2015, s. 365). Tento koreň by dal podl'a Kortlandtovej interpretácie Winterovho pravidla v praslovančine akút nad *a, čo však rekonštruovat’ nemožno (pozri Derksen, 2008, s. 320 - 321). L. Králik ale ponúka aj výklad, podla ktorého sa praslovanské *modrъ spája s anglickým madder ,marena farbiarska', čo má byt’ z germánskeho *madrōn (Králik, 2015, s. 365). $\mathrm{S}$ ohl'adom na Winterovo pravidlo musíme potom toto asi uprednostnit', a to bez ohl'adu na to, či budeme následne uvažovat' o indoeurópskom koreni * mod $^{h}$ - alebo o prípadnom slovanskom prevzatí z germánčiny.

Slovenské nevesta pochádza naopak z praslovanského *nevè̀sta s akútom, ako vyplýva aj zo staroslovienskeho nevěsta, srbského a chorvátskeho nèvjesta, čakavského nevïsta, nevësta, slovinského nevẹsta, bulharského nevésta, nevjásta, mace- 
dónskeho nevesta, českého nevěsta, staropol'ského i pol'ského niewiasta, lužickosrbského njewjesta, ruského nevésta, ukrajinského nevista a bieloruského njavésta (pozri Derksen, 2008, s. 351; ESJS 9, 1999, s. 541). V Stručnom etymologickom slovniku slovenčiny sa uvádzajú dva výklady, a to že pôvodným významom mohlo byt' ,neznáma“ a v takom prípade ide o zloženinu ne- a praslovanského *věsta $<$ *věd-ta ako príčastia od véděti, lebo nevesta bola $\mathrm{v}$ manželovej rodine málo známym človekom, no označenie mohlo mat' azda aj tabuové súvislosti; na druhej strane však mohlo byt' vraj pôvodným významom aj ,novo privedená", teda *nevo-věsta, kde nevo- súvisí s praslovanským *novъ (> nový) a *věsta je príčastím od praslovanského *vesti (> viest') (pozri Králik, 2015, s. 386 - 387). V rámci Winterovho pravidla by sme však mali druhý výklad najskôr vylúčit, lebo *vestì patrí do cirkumflexovej Stangovej paradigmy AP (c).

Napokon posledný slovenský výraz z nášho výpočtu pôjd pochádza podl’a L. Králika z praslovanského *podz, čo má súvisiet' so staroindickým padám ,krok, stopa nohy', gréckym pedon ( $\pi \dot{\delta} \delta o v$ ) ,pôda', litovským pãdas ,podošva' a podobne, východiskom majú byt' indoeurópske korene *ped-, *pod- ,noha; chodit', padat", resp. ich dlhé varianty. Pôvodným významom praslovanského *podъ malo byt' asi ,chodenie', z toho ,po čom sa chodí‘ a z toho ,zem, zemina', ako vidíme v slovenskom pôda, a slovo mohlo vraj označovat' aj hlinenú dlážku na hornej strane stropu, pričom nemožno azda vylúčit' ani druhotný vplyv etymologicky nesúvisiaceho nemeckého Boden (v nárečiach i [poden]), prst', zem; podlaha; povala“ (pozri Králik, 2015, s. 463).

R. Derksen (2008, s. 408 - 409) však na základe srbského a chorvátskeho pôd, G sg. pöda, čakavského pöd, G sg. podä, slovinského pòd, G sg. póda, bulharského pod, českého půda, staroruského podb, ruského pod, G sg. póda, nárečovo pôd, G sg. pôda, ukrajinského pid, G sg. póda rekonštruuje k slovenskému pôjd praslovanské *podb, čo ho vedie $\mathrm{k}$ neprijatiu uvedeného typu etymológie, pri ktorej by $\mathrm{v}$ rámci Winterovho pravidla mal byt' z indoeurópskeho *pod- praslovanský akút nad $* a$, a uprednostneniu skôr takého typu výkladu, ktorý nájdeme napríklad aj u J. Rejzka, teda že ide o zloženinu z indoeurópskej predložky * po a odvodeniny od koreňa *dhe ,klást" (pozri Rejzek, 2001, s. 517), t. j. bez potenciálnej glotálnej hlásky. Tento typ výkladu by sme pri prísnom dodržiavaní Winterovho pravidla mali potom zrejme uprednostnit'.

Na záver môžeme povedat', že predložený krátky rozbor v prvom rade aspoň čiastočne dokázal, akou nesmierne náročnou úlohou je tvorba tisícov hesiel etymologického slovníka a aká komplexnost' myšlienok sa skrýva pod pokojným vzhl'adom vel'kej časti z nich. Menej presvedčivo ukázal, že Winterovo pravidlo má zásadný význam pre inak obdivuhodný Stručný etymologický slovník slovenčiny ako celok. Môže sa viac-menej dotýkat' len ôsmich základných výrazov v ňom, teda $b o h$,

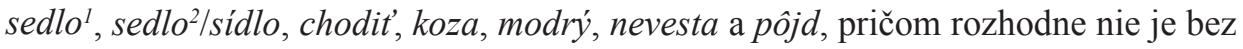
zaujímavosti, že až pri troch $\mathrm{z}$ nich sa hl'adá pôvod v tom istom indoeurópskom ko- 
reni *sed-. Na základe rigorózneho pridržiavania sa Winterovho pravidla by sme v každom prípade mali asi pripustit', že v prípade prvých piatich pomenovaní nepôjde o slová pochádzajúce $\mathrm{z}$ indoeurópskeho prajazyka, lež o praslovanské výpožičky z iránčiny (boh a prípadne aj chod), altajských jazykov (koza), resp. germánčiny $\left(\right.$ sedlo ${ }^{1}$ a sedlo ${ }^{2}$ ), a v prípade zvyšných výrazov počítat' so spresneným (modrý a nevesta) či odlišným (pôjd) etymologickým výkladom.

\section{Bibliografia}

BEEKES, Robert: Etymological Dictionary of Greek. Leiden - Boston: Brill 2010. 1808 s.

DERKSEN, Rick: Etymological Dictionary of the Slavic Inherited Lexicon. Leiden - Boston: Brill 2008. $726 \mathrm{~s}$.

DERKSEN, Rick: Etymological Dictionary of the Baltic Inherited Lexicon. Leiden - Boston: Brill 2015. $684 \mathrm{~s}$.

ESJS 2 - Etymologický slovník jazyka staroslověnského 2. blag - dělo. Hl. red. E. Havlová. Praha: Academia, nakladatelství Československé akademie věd, 1990, s. 65 - 128.

ESJS 4 - Etymologický slovník jazyka staroslověnského 4. gospodb - istnoti. Doplňky k bibliografickému aparátu I. Hl. red. E. Havlová. Praha: Academia, nakladatelství Akademie věd České republiky, 1994, s. $193-252+$ I - IV.

ESJS 6 - Etymologický slovník jazyka staroslověnského 6. klęti-kuditi. Hl. red. E. Havlová a A. Erhart. Praha: Academia, nakladatelství Akademie věd České republiky, 1996, s. 317 - 380.

ESJS 9 - Etymologický slovník jazyka staroslověnského 9. mrъkati - obrěsti. H1. red. A. Erhart. Praha: Academia, nakladatelství Akademie věd České republiky, 1999, s. 503 - 566.

ESJS 10 - Etymologický slovník jazyka staroslověnského 10. obrěsti-patěna. Hl. red. A. Erhart. Praha: Academia, nakladatelství Akademie věd České republiky, 2000, s. $567-630$.

ESJS 18 - Etymologický slovník jazyka staroslověnského 18. větı-zakonъ. Hl. red. I. Janyšková. Brno: Tribun EU 2016, s. 1059 - 1122.

ESSJ 8 - Этимологический словарь славянских языков. Праславянский лексический фонд. Выпуск 8. *ха - *jьvыlga. Hl. red. О. Н. Трубачев. Москва: Наука 1981.

KORTLANDT, Frederik: Remarks on Winter's Law. In: Dutch Contributions to the Tenth International Congress of Slavists, Sofia. Amsterdam: Rodopi 1988, s. 387 - 396.

KORTLANDT, Frederik: Winter's Law Again. In: Accent Matters: Papers on Balto-Slavic Accentology. Amsterdam: Rodopi 2011, s. $245-250$.

KRÁLIK, Lubor: Stručný etymologický slovník slovenčiny. Bratislava: Veda 2015. 704 s.

KROONEN, Guus: Etymological Dictionary of Proto-Germanic. Leiden - Boston: Brill 2013. $794 \mathrm{~s}$.

MACHEK, Václav: Etymologický slovník jazyka českého. Praha: Academia, nakladatelství Československé akademie věd, $1971.868 \mathrm{~s}$.

PUKANEC, Martin: Etymologický nákres slovanského sveta bohov a démonov (náboženstva a morálky Slovanov). Nitra: Univerzita Konštantína Filozofa v Nitre, Filozofická fakulta, 2013. 148 s.

REJZEK, Jiří: Český etymologický slovník. Voznice: Leda 2001. 752 s.

Slovník súčasného slovenského jazyka A - G. Hl. red. K. Buzássyová - A. Jarošová. Bratislava: Veda 2006. $1134 \mathrm{~s}$.

WINTER, Werner: The distribution of short and long vowels in stems of the type Lith. Asti : vèsti : mèsti and OCS jasti : vesti : mesti in Baltic and Slavic languages. In: Recent Developments in Historical Phonology. The Hague - Paris - New York: Mouton 1978, s. 431 - 446. 